\title{
THE PASSING OF TWO GREAT SWISS CHEMISTS.
}

\section{P. A. GUYE and T. SANDMEYER.}

With the passing of Guye and Snndmeyer, Swiss chemistry has sustained two losses which aro also the losses of science; for science is universal. Both were men of exceptional worth in scientific attainment and personality, and it is very difficult to realise that they are no more. The writer of these lines enjoyed the great privilege of intimate association with them-with Guye as an esteemed friend and collengue, with Sandmeyer as a technical collaborator for nearly eight years.

\section{PHILLIPE, A. GUYE.}

Phillipo Guye was horn in Saint-Christophe, Canton do Vaud, Switzerland, on Juno 12, 1882 . Ho studied in Geneva and in Paris, graduating at both universities. After a long residence in the French capital, during which ho worked under Friedel, Guye was called to tho University of Geneva, whero his output of scientific work was prodigious. His papers aro so numerous that it is impossible to givo an adequate account of them, even in outline; nearly 200 papers emannted from his laboratory, and the publications which bear his name number over 800 and cover more than 10,000 pilges.

Following a number of researches in organic cliemistry, Guye concentrated his energies on physical chemistry, a field in which ho discovered new and fundamental relationships between tho physical constants of fluids and their chemical constitution, especinlly with regard to tho sizo of molecules; and concurrently with theso extensive researches he developed his original and brilliant theory of the dissymmetry of molecules, which ho supported with an almost incredible array of facts and other evidence.

From 1903 ho turned to the field which ho mado particularly his own, viz., the determination of atomic weights. IIe was the author of over 100 papers relating to the atomic weights of nitrogen, chlorine, and bromine, and it is impossible to overrate the accuracy of his work, which is second to none in this fundamental branch of chemistry. Tho accuracy which Guye attained in this work, $1: 10,000$, has never been surpassed; and he obtained these marvellous results without the aid of costly apparatus, for tho University of Cienera is not rich; his manual dexterity and his scientific flair overcame overy difficulty. His resen rehes on atomic weights represented a distinct advance on thoso of Marignac and Stas.

During all this time Guyo nover lost contact with the techuical world. His investigntions on. the combination of nitrogen and oxygen under the influence of the electric arc gave rise to a number of fundamental patents, and his motive in doing this work was to enable Switzerland to produco all its requirements in nitrogenous fertilisers by developing its great water-powor resources, amounting to 4 million h.-p.

Having always rogretted that Switzerland had no periodical chemical literature of its own, Guye founded his Journal de Chimie Physique, and ho took a very active part in founding tho IIclvetica Chimica Acla.

Honours poured upon him. Ho presided in turn over practically every chemical socioty in Switzerland, and was $n$ menber of tho International Conmitleo on A tomic Weights. France mudo him a Chovilier do la Jégion d'Honneur, and gnvo him tho Prix Vaillnnt. The Royal Socioty, in addition to awarding him the Davy Medal, mado him an honorary member; and a similar honour was bestowed upon him by tho chemical societies of Madrid, London, Petrograd, and Bucharest.

'To the writer all tho honours and success which fell to Guye's lot were of littlo significance in comparison with his personality. He was a most sincero friend, a most conscientions teacher and investigator, and a brilliant lecturer. His tact was recognised in every quarter, and aithough for him scienco had no frontiers, his sympathies wero decidedly with France; Guye, with his magnificent sympathy, was the true link between tho belligerent nations. His carly death is sincerely regretted, not on account of unfinished work-work is never finished-but becauso men of his stamp, personality and world-wido reputation aro rare and irreplaceable.

\section{T. SANDMEYER.}

In many respects Traugott Sandmeyer and Phillipo Guyo represented two very distinct types. Sandmeyer was scarcely known outside tho small circle of his collaborators and colloagues, ho disliked publicity in every form, and althongh his life was devoid of startling adventures and great worldly successes, nevertheless, it was not without romanco. His method of investigation and his manner of working differed so much from those of other chemists that everyone who camo in contact with Sandmeyer felt that his porsouality was not an ordinary ono and that ho wns capable of doing things which only genius can achieve. For this reason and because his ideas were inimitable and brilliant, ho had no enemies, and oven enry passed lim hy. The clue to all his successes was his extraordinary faculty of observation; he could dotect the slightest deviation in a renetion and his discovery of a new method for synthesising indigotin was the result of this exceptional power, together with the gift of chemical divination. As a colleague he was always roady to help and advise, never expecting or desiring thanks. Most of tho apparatus he used was of his own construction, for he was an expert mechanician. During the construction of the great dye-house in the Basle factory in 1918, ho communicated to the architect his "feeling" that the reinforcement of the concreto was not one-third of the strength required, and on investigation it was found that a mistake had been mado which would certainly have caused tho five-story building to collapse. Owing to his conscientious method of work, to to his assistant was no easy task, not becauso ho was an exacting master, but becauso ho would perform every experiment himself; in fact, ho had only ono assistant, namely, himsolf, and a renction which ho had not seen did not exist for him. Tho discovery that 1.2.4-nminonaphtholsulphonic acid can be diazotised, contrary to the statement of Otto N. Witt, was mado because Sandmeyer tried not only naphthol as a coupling agent but also resorcinol, which couples much more readily with the minuto yuantity of diazo-compound that is formed, in spito of Witt's assertion. His discovery" of the "Sandmeyer reaction" is another exnmple of his power of observation, and there aro many others. Entering tho Goigy factory in 1888, ho brought with him tho constitution of Primulino, discovered by Green, and he told the writer that it took him but a fow hours to find out (by distillation with rinc) thint Primuline is related to thiotoluidine. But before 1888 Snndmeyer was alrendy well known to organic chemists for his discovery of 
the "Sandmeyer reaction" and the dangerous esters of hypochloric acid, and he was also the discoverer of thiopliene."

$t$ 'The first result of Sandmeyer's studies in Basle was the discovery of diamidophenyltolyl, which enabled tho Geigys to imitate all the Benzidino colours with the homologue. In 1859 he prepared Chrome Violet by concensing salicylic acid with formaldehyde and oxidising with nitrous acid, reaction which was of great technical importance as it gavo rise in later years to the beautiful series of the Azurols and the Aurins of the Malachite-Green series. In the same year he discovered his remarkable process for making Auramine (from tetramethyldiamirlodiphenylmethane, sulphur, ammonium chloride and ammonia), carrying out the reaction in a kettlo of his own construction. The year 1890 saw the discovery of the important method for producing dyes of the triphenylmethane
Setopaline, Setocyanine, Brioglnucine Supra, and a number of intermedintes which were more of seientific interest. Sandmeyer was the first to discover that a sulplionic group in the orlho-position to the carbinol-group in tho triphenylmethanc-dyes gives rise to the Patent Blues, and that tho methylgroup has a similar action.

The years 1887-1899 vielded new and hirhly intercsting results of a scientific character. Ho made the $p$-aminobenzaldelyydes by the action of hydroxylamine-derivatives on formaldehyde-derivatives and amines; and p-dimethylaminobenzaldehydes, which play an important part in the diagnosis of syphillis were prepared in almost unlimited number. Ho also mado a number of aldehydes (e.g., ranillin, naphthaldehydo) by a modification of the Tiemann-Reimer method, and theso compounds proved to be important in the manufacture of colours of the Naphthalene-Gicen typo.

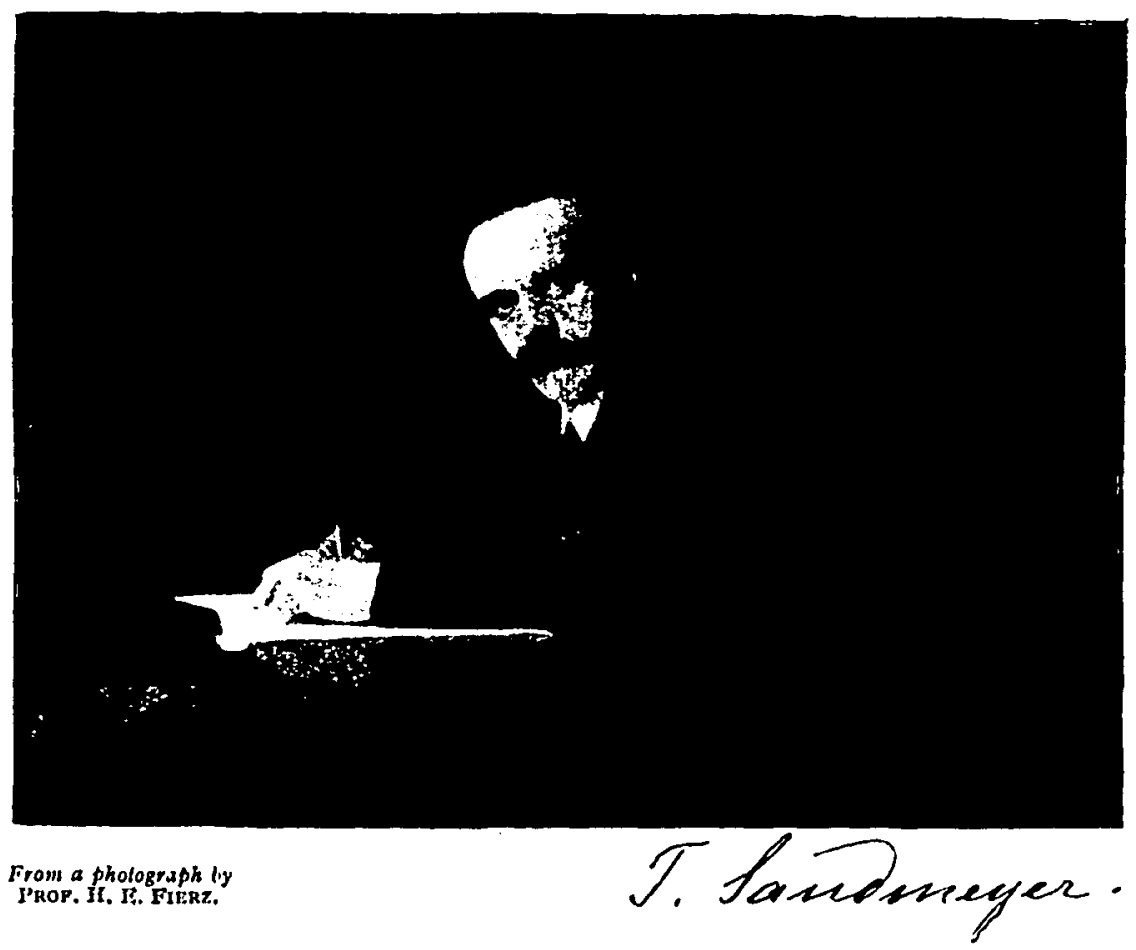

clabs (6tarting from tho hydrol) which is now in very general use in dyo-manufacture (Acid Violet 5B, BB). The following yoar he made the disulphonic acid of nmidophenol (2.6.4) by the action of bisulphite on $p$-nitrosodiethylaniline, and found that formanilide when reduced with yinc-dust yields pure monomethylaniline, which at that time was needed in the manufacture of antipyrino. His achiovements in the field of triphenylmethane-dyes wore particularly numerous in the succeeding years; he mado Ilelvetia Blue, Erioglaucino,

- Bandmoyer, whose voractly is loyond nny doubt, told the writer the story of this discovery, which dilfers slightly froin the version gonerally accepted. Vlctor Neyer wanted ho flow to his stindents the well-klown lgatin renctlon of Lenzene with concentrated eulphurle arld. 'Tho benzono lind Just ween prepared, during tlue locturo from benzoate, but tlie red colour dld not npjoin. Nloyer ko impationt, so sandineser gavo him a drop of beizene from a bottlo on the shell "to lo ". In inclont ontro to $t$ The succeding three parugraphs aro bised on notas supplied by Dr. II. IIagenbach.
The year 1899 saw Sandmeyer's most romarkable achievement, viz., the preparation of indigotin from thiocarbanilide by a method which, although used only for a short time, appenrs to lo one of the most hrilliant in technical organje chemistry. In $] 904$ Sandmerer showed how to diazotise the 1,2,4-amidonaphtholsulphonic acids from which wero obtained Erio Clirome Blueblack $\mathbf{B}$ and $\mathbf{R}$, Chrome Black ' $\mathbf{T}$ and $A$, and Erio Chrome Red 13 . Later, ho prepared Erio Chrome Azurol and similar dyes by tho reaction ho had used in discovering Chrome Violet. During the war ho took n very active part in the manufacture of the naphthalene-derivatives which the Baslo manufacturers had proviously bought from Gormany. His last achiovemont was the finding of a now nnd very importunt mothod for manufacturing isatins, starting from amines, dhloral and hydroxylamines, a method which gives guantitative yiokls and whose discovery showed that Sandmeyer was still the master of the subject.

On his retirement in 1919 , Sandmoyor gave a large portion of his wonlth to the pension fund of the firm for which he had worked during 31 years, 
and he retired to Zollikon, near Zïrich. After a short illness, which was followed by an operation, he passed away early in April, in his 68th year.

Tho following ndditional facts were written by Sandineyer a few weeks before he died.

Sandmeyer was born in Weitingen (Aargau) in 185.1, on the day before the death of his father, who was a leacher of natural science and agriculturo. Owing to this calamity, his mother had to resume her former occupation of school teacher, at Aarau, where 'Traugott attended the communal school. Stimulated by reading scientific books from his father's librars, he developed a great interest in physical apparatus and manual work, so that instend of proceeding to the cantonal school he entered an engineering Worksliop.

Three years later ho obtained emplorment in the mechanical and optical slop of $\mathrm{J}$. F. Meier, of Zürich, but his lealth failed, and his mother having como to live in Yiirich, lre started a workshop in his own home and supplied apparatus to the chemieal departments of the Federal Polytechnic. In this way ho was brought into contact with the professorial staft, and in 1882 he becance lectureassistant to Victor Meyer, and soon started investigations which were published subsequently in the Berichte. In 1885 ho accompanied Victor Aleyer to Göttingen for one semester, and then returned to Ziirich, where he served for three years under Hantzsch. In 18S8, after three offers from dyemanufacturers, he joined the firm of J. R. Geigy, thus realising his secret wish to enter a technical branch of chemistry. In 1892 he married his stepnieco Mlina Billetor, of Mïnnedorf.

In recognition of his work, the University of Ileidelbers conferred upon him, in 1891, the degree of Phil. Doc., honoris caust. 'I'en vears later he was anpointed a director of J. R. Cieigy and Co. which was then converted into a limited liability company; and whon tho firm celebrated its $1 \tilde{0} 0$ th anmiversiry in 1915, he was mide an lonorary doetor of the 'Technienal "Hochschnle," Zurich.

The lives of Guye and Sindmeyer apmear to have little in common; but those who know them intimately cannot accept this view. Guye and Sandmoyer represent the typo of scientific men, like Bayer, Bunsen and Emil Fischer, which pursues seience for its own sake. These groat men never played any part in so-called society; and as wo look around us we can but reuret the disappearance of this school. Bon and Isler, too, hare gone; colou cliemistry seems to bo it the end of its wisdom.

Sundmeyer and Guve were very different from many industrial chemists of the present timo, and the iden that money comes hefore science could never have entered their heads. What would they have thought of so-called chemists who livo by imitating their competitors and who eren bonst of appropriating tho jeas of others? 'Tho young generation which has not seen a really great chomist at work overlooks only too rendily tho fundamental differenco between knowledge which hats been gained through original research and knowledge which has been learned from books and other second-hand sources. Every one of the truths which have been brought to light by these great and modest men entailed long years of hard, self-denving work. 'l'hey ropresented the new ideas; they were tho incarnation of science. Havo tho younger men tho genius and tho sense of modesty which alono bring lasting success? Havo thoy tho necessary power of persistent offort? This question scoms tho most importunt outcomo of the lives of theso two men. 'Tlicir work wis truly remarkablo, but tho examplo they havo set overslundows oven tho grentuess of their nchicroments.

H. F. Finu\%.

\section{ACETYLENE IN TECHNICAL CHEMICAL SYNTHESES.}

'The reactivity of acetylene renders it very useful in many chemical syntheses, and production at a low price is the only consideration determining the practical use of this gas in many well-known reactions. Such products as acetic acid, ethyl alcolsol, acetal, aldol, and chlorine-containing solvents can be manufactured by reactions easily adaptable to large-scale operations, and tho newor synthetical methods will come to the fore, in competition with older processes, so soon as the initial raw material, calcium carbide, is availablo at low cost.

The manufacture of calcium carbide involves tho expenditure of over $4000 \mathrm{kw}$.-hr. of electrical power per ton of carbide, and if this power is available at, say, 0.1d. per unit, carbide will be manufactured it il cost of $\mathcal{L i j}^{-}$per ton (cf. Report of the Nitrogen Products Committec, 1919). With power at about 0.33d. per unit, carbido could be produced at less than 210 per ton. 'Thus, countries possessing largo water-power resources should be in an excellent position to manufacture cheap carbide, and, indeed, lefore the war, Norway generated power it 0.07d. per unit.

Many reactions which to-day are merely laboratory methods of preparation have been thoroughly investigated in large-scale apparatus and only await chenp acetylene for competitive manufacturo to be commenced.

No attempt at collective recording of the possibilities of acetyleno in industry has been mado, so far as the writer is aware, except a flow-sheet published by Desehiens (Chim. et Ind., 1921, 239). It in, therefore, proposed in this article to discuss the methods avalable for producing acetaldehyde, acetic acil, hydrogen cyanide, and condensition prolucts such is pyridine, pyrrole, thiophene, but detailed estimates of costs of production oannot be considered owing to limitations of space. It should, however, becomo apparent that many of the methods to bo considered are quite capable of technical realisation, and the costs of actual operation being relatively small, all that is required for economic sucens is clieap calcium carbide. 'l'o quoto but a single example in advance, there seems every possibility that ethyl alcoliol could to produced sjuthetically at about 1s. Gal. per gallon, provided calcium carbicle is obtainable at s6 per ton, a likely figure in localities where cheap liydro-electric power, coal and limestone are available.

\section{Arelaldehyde and Acetic Acid.}

The manufacture of acetaldehyde from acetylene by eatalytic hydration in the presence of mercuric salts is catalysts, and the oxidiation of tho aldehyde to acetic acid, have been deseribed previously by the writer (c. J., 1)21, $3415 \mathrm{n}$ ). 'That the processes involved aro capable of practical application is shown by tho results of the operations of the Canndian Wilectro Products Co. of Meister, lucius and Brüning, of the British Cellulose Co., and others. Tho commercial success of the process for manufacturing synthotic acid dopends essentinlly upon tho cost of calcium-carbido production, and when this cost becomes sufliciently low, it will bo pussible to manufacturo economically muny derivatives of acotic acid and ncetylene. Thus, acotono can be produced by passing acetic acid over dehydrating catalysts at about $400^{\circ} \mathrm{C}$., and tho following long rango of products may all bo regarded as dorivatives of acolyleno: tho acetates, acotyl chlorido and anlydride, ethylidene diacetato, ncetyl derivatives of organic neids, e.u., ncetylsalicylic acid, and 